\title{
СЕМАНТИЧЕСКАЯ СТРУКТУРА ЛЕКСЕМЫ ЛЕБЕДЬ В ИСТОРИИ РУССКОГО ЯЗЫКА
}

\section{Semantic Structure of the "Swan" Lexeme in the History of the Russian Language}

Keywords: semantics, historical lexicology, ethnolinguistic, lexis

Contact: МГОУ; a_ulyanenko2000@mail.ru

Любое слово как основная структурная единица языка выражает определенное лексическое значение или совокупность значений. В основу его номинации могут быть положены определенные образы или идеи, мотивирующие семантику слова, о чем писал еще А. А. Потебня в книге «Мысль и язык». Под внутренней формой он понимает «(...) ближайшее этимологическое значение слова, тот способ, каким выражается содержание» (Потебня 1989: 160). Внутренняя форма слова - это след того процесса, при помощи которого оно было создано.

Изучению лексемы лебедь в различных аспектах посвящены работы С. В. Мироновой (Миронова 2013: 117-121), М. В. Пименовой (Пименова 2017: 62-71), в которых рассмотрение орнитонима проводится с точки зрения лингвокультурологии и языкознания, а особое внимание уделяется символическому смыслу слова. Согласно приведенным источникам, частотность лексемы лебедь характеризует ее, как одну из наиболее значимых лингвокультурем современного русского языка, которая помогает составить более полное представление о ценностной картине мира русского человека. Уникальность настоящего исследования состоит в раскрытии эволюции лексического значения слова лебедь в истории русского языка. Данная работа является результатом исследований, проведенных Лабораторией палеолингвистики и региональной лексикографии под руководством А.В. Войтенко.

Целью нашего исследования является анахронический анализ семантической структуры лексемы лебедь - выявление постепенных изменений в семантической структуре этого языкового знака с опорой на употребление 
лексемы в речевых контекстах, зафиксированных в толковых и исторических словарях.

Лебедь издавна считается священной птицей в русской мифологии и культуре. В христианстве его образ связывается с чистотой, милосердием и обликом Девы Марии. Славянская мифология интерпретирует данную птицу в качестве символа возрождения, целомудрия, гордого одиночества, пророческих способностей, красоты и совершенства. Существуют представления о способности души странствовать по небу в образе лебедя. Сочетая в себе две стихии: воздуха и воды, лебедь является птицей жизни, и в тоже время может олицетворять смерть. В связи с этим интересно противопоставление в мифах и сказках белого и черного лебедей (жизнь - смерть, добро - зло).

В культуре лебедь рассматривается как птица поэтов, а «лебединая песня» (песня умирающего лебедя) - как последнее значительное творение выдающегося человека.

В современных реалиях лебедь остается столь же глубоко почитаемым практически все его биологические виды занесены в Красную книгу России, а отдельные из них (например, лебедь-шипун) - и в региональные. Также существует народное поверье, в соответствии с которым убийство лебедя может навлечь несчастья на человека. Обывательское представление о птице характеризуется положительными эпитетами, выделяющими грациозность движения и красоту лебедей.

Лексема лебедь, согласно «Школьному этимологическому словарю русского языка» Н. М. Шанского и Т. А. Бобровой, «является общеславянской и представляет собой суффиксальное производное от той же основы, что и лебеда, лат. albus 'белый', нем. Эльба и т. д.» (Шанский, Боброва 2004: 165). Исходной основой является праславянское *elbedb, а сама птица названа по белому цвету оперенья. Появление слова для ее обозначения связывают с XI веком.

В контексте нашего исследования используется 28 лексико-семантических вариантов лексемы лебедь, встречающихся в пределах лексикографических и литературных источников. Для начала мы выделим номинативное значение и его вариации среди переносных. Затем обратимся к метафорическим и метонимическим аспектам употребления языковой единицы, которые располагаются в соответствии с эволюцией ее семантики, а также проанализируем грамматические категории слова (род, число, одушевленность / неодушевленность) для выявления закономерностей изменений в его семантической структуре. 
Первичное значение орнитонима представлено в «Словаре русского языка XI-XVII вв.» в контексте примера из сборника правовых норм Киевской Руси «Русская правда»: «Въ гусъ, и в жэравђ, и въ лебеди 30 рьзанъ» («За гуся, журавля и за лебедя платить 30 резан (владельцу)») (Филин 1981: 183). Уже на данном этапе прослеживаются предпосылки к изменениям во внутренней форме слова, так как номинация содержит скрытую метонимию - под лебедем / лебедью понимается птица как имущество, за кражу которого налагается штраф в определенном размере.

Прямое значение имеет форму как мужского, так и женского рода (для обозначения самца и самки птицы), единственного или множественного числа, стилистически нейтрально и служит мотивирующим для большинства переносных.

Начиная с XX века назывное значение лексемы лебедь дополняется эпитетами и характерными внешними и поведенческими признаками, присущими данной птице. Так, в «Толковом словаре русского языка» под ред. Д. Н. Ушакова лебедb - 'большая красивая водяная птица, с длинной шеей и плавными движениями’ (Ушаков 1935-1940). «Русский семантический словарь» под ред. Н. Ю. Шведовой дополняет эти характеристики особым примером - «Пара лебедей» - (Шведова 2002: 437), выделяющим еще одно свойство поведения птицы - моногамность. Особо стоит отметить дефиницию, приведенную в этнолингвистическом словаре «Славянские древности: Этнолингвистический словарь», где лебедь - 'птица, сочетающая в себе разнородные черты, одни из которых сближают ее с аистом, другие, слабее выраженные, объединяют с уткой (Толстой 2004: 88). Здесь внешние признаки лебедя описываются через сравнение с другими, ему подобными птицами. По данным Национального корпуса русского языка, в современных источниках номинативное значение утрачивает прежнюю широту распространения.

Далее в семантике слова происходят преобразования, которые можно обозначить как семантический сдвиг (перенос) значения по сходству (метафора) и по смежности (метонимия).

Наиболее употребительным становится метафорическое значение лексемы. В контексте метафоры лексема лебедь реализуется в нескольких лексикосемантических вариантах.

Первый из них - «О созвездии Лебедя» - упоминается в «Словаре русского языка XI-XVII вв.» в качестве второго значения (Филин 1981: 183). Время его появления связывается с XI веком. Семантика орнитонима содержит метафору по 
форме (крестообразный рисунок созвездия напоминает фигуру летящего лебедя). В «Словаре церковно-славянского и русского языка» 1847 года к приведенной дефиниции прибавляется указание на расположение звездного скопления «Северное созвездие» (1847: 247). Родовая принадлежность значения (только мужской род) устанавливается в «Большом толковом словаре русского языка» под ред. С. А. Кузнецова. В нынешнее время употребление данного лексикосемантического варианта характерно для научно-публицистических материалов.

На основе метафоры по форме и / или цвету последовательно возникает и ряд других значений: «Ковш, кубок в виде лебедя» (Филин 1981: 183); «Кривощип, змейка» - подъемный механизм, который в будущем приобретет название «лебедка» (Филин 1981: 183); «Музыкальный инструмент вроде гуслей» (СРНГ 1980: 302).

Среди них особо выделяются фразеологически связанные значения: «Лебеди летят (лететь)!»- приветствие / пожелание человеку, моющему пол или стирающему одежду (СРНГ 1980: 301); метафора белого цвета птицы применяется по отношению к будущему результату хозяйственной деятельности человека - хорошо выстиранному белью или вымытому полу.

Также активно развиваются и используются антропоморфные значения, заключающие в себе метафору по внешнему и поведенческому сходству. Наиболее известный пример - крылатое выражение «Лебедь, рак и щука», появившееся в одноименной басне И. А. Крылова 1814 года. Лебедь предстает в качестве собирательного образа человека, как и общее значение фразеологизма: «О тех, кто действует несогласованно, вразнобой» (Шведова 2002: 437).

Не менее употребительным является основанное на мифологическом контексте значение 'мифологического и поэтического образа красавицы женщины’ (Ушаков 1935-1940). Его появление можно связать с эпохой XIX века - золотым веком русской литературы. Значение имеет фольклорный характер, употребляется только в форме женского рода, свойственно народнопоэтическому языку, а также представлено в положительной коннотации. Образ Царевны-Лебеди формируется на основе преданий о красавицах-девушках, превращающихся в этих птиц.

Существует и отрицательная коннотация данного значения: «- Кто такая, - спрашиваю, - эта Настя Королева? А сам думаю, ну, наверняка, какая-нибудь царевна-лебедь с короной на голове» (НКРЯ). Связано это с легендой о Лыбеди - сестре основателей Киева, отличавшейся гордым нравом, обрекшим ее на одиночество. 
Сейчас лексема лебедь в подобном отношении используется для обозначения красивой девушки с чистой душой и добрым сердцем, что чаще всего выражается в форме обращения к ней: «Тебе неловко сидеть, Платонида! Сядь, лебедь, сюда ближе» (Евгеньева 1999: 167).

Особый подтип метафор составляют символические контексты употребления слова. Ярким примером этого является выдержка из древнерусского памятника письменности «Слово о полку Игореве»: «Боянъ же, братіе, не .Г. соколовъ на стадо лебедъи пущаше, нъ своя вђщіа пръсты на живая струны въскладаше; они же сами княземъ славу рокотаху» («Боян же, братья, не десятку соколиную на стадо лебединое пускал, но свои вещие пальцы на живые струны воскладал - они же сами князьям славу рокотали») (Срезневский 1902: 1314).

Здесь представлена звуковая метафора, основанная на символике совместного употребления лексем лебедь и сокол; сокол, настигающий лебедя это пальцы певца-рассказчика (Бояна), касающиеся струн, под которыми подразумеваются лебеди. Крик пойманной птицы олицетворяет звук игры на музыкальном инструменте.

Из 28 значений, взятых для анализа, явно выраженный номинативный характер представлен в 3-х значениях, метафорическим контекстом обладают 23, метонимический имеют 2 значения.

Реализация метафоры в форме одушевленного существительного мужского рода связана с номинативным значением. Основой для переноса в данном случае служат поведенческие особенности птицы: «Лебедь благородный дней Екатерины / Пел, прощаясь с жизнью, гимн свой лебединый...» (НКРЯ). Речь идет о поэте А. С. Пушкине, а использованный в контексте примера зооморфизм формируется на мифологической основе, где описанное поведение свойственно птице за несколько мгновений до ее смерти.

Употребление лексемы с метафорической семантикой в женском роде исключительно в форме одушевленного имени существительного связано с мифологическим контекстом, где лебедь является символом красоты, чистоты и целомудрия. Под лебедью понимается молодая девушка, обладающая соответствующими чертами внешности и характера: «Лебедь белая молчит и, подумав, говорит...» (Ушаков 1935-1940). Данная форма употребляется в народно-поэтическом языке для создания образности.

Неодушевленными являются варианты лексемы мужского рода или обоих родов (женского и мужского). Метафора в данном случае строится за счет 
ассоциаций с внешними признаками птицы (форма, цвет), которые присваиваются предметам или явлениям.

Метафорический контекст употребления лексемы лебедь эволюционировал от внедрения внешних признаков птицы к выделению особенностей поведения лебедя и их проекции на человека, предметы или явления.

Метонимический перенос свойственен исключительно значениям лексемы с категорией неодушевленности: «Она вышивала салфетки, а я рисовал коврики русалок и лебедей» (НКРЯ); «Первым блюдом были всегда жареные лебеди» (НКРЯ). Такой тип изменения внутренней формы слова носит более редкий характер употребления и связан с его первичным значением.

Дальнейшие исследования в области лексемы лебедь и способов ее номинации могут быть направлены на сопоставление структуры семантики данного слова в русском и любом другом языке для выявления сходств и различий в его внутренней форме.

\section{Summary}

As a result of the analysis of 28 contexts of the use of the "swan" lexeme, the following patterns of transformation of its semantic structure were identified: transition from the common sphere to the household (dialect lexis), scientific, and then - to the spiritual. There is also an evolution in the nature of nomination from rational to emotional. Changes in the semantic structure of the "swan" lexeme led to the appearance of homonyms as a result of the disintegration of polysemous word. This once formed process became the basis for the emergence of new forms of use of this ornithonim.

\section{Резюме}

В результате анализа 28 контекстов употребления лексемы лебедь были выявлены следующие закономерности преобразования ее семантики: переход из общеупотребительной сферы в бытовую (диалектная лексика), научную, а затем - в духовную. Также наблюдается эволюция в характере номинации лексемы от рационального к эмоциональному. Изменения в семантической структуре лексемы лебедь привели к образованию омонимов на основе распада многозначного слова. Именно этот некогда сформировавшийся процесс служит базой для появления новых форм употребления данного орнитонима. 


\section{Литература}

Даль, В. И. Толковый словарь живого великорусского языка: в 4-х т. T. 2: И-О. Санкт-Петербург; Москва: Типография М. О. Вольфа, 1881.

Евгеньева, А. П., Разумникова, Г. А. (ред.) Словарь русского языка: $B 4$ m. Т. 2: $K-O$. Москва: Русский язык, Полиграфресурсы, 1999.

Кузнецов, С. А. (гл. ред.) Большой толковый словарь. Санкт-Петербург: Норинт, 2000.

Миронова, С. В. Лексема «лебедь» в современном русском языке: лингвокультурологический аспект. Филологические науки. Bопросы теории и практики. 2013 (27/9), с.117-121.

Нацииональный корпус русского языка. Режим доступа: http://processing.ruscorpora. $\mathrm{ru} /$ search.$x m l$ env $=$ alpha \&mycorp $=\&$ mysent $=\&$ mysize $=\&$ mysentsize $=\& \mathrm{dpp}=$ $\& \mathrm{spp}=\& \mathrm{spd}=\&$ mydocsize $=\&$ mode $=$ main $\&$ sort $=$ i_grtagging $\&$ lang $=$ ru $\&$ nodia $=1$ \&text=lexform\&req=лебедь (2020-03-20).

Пименова, М. В. Лебедь: слово \& символ. In: Морозова, О. Н., Пименова, М. В. (eds.) Язык, культура, этнос: сборник научных статей. Санкт-Петербург: Издательство СПбГУ, 2017, с. 62-71.

Потебня, А. А. Мысль и язык. In: Потебня, А. А. Слово и миф. Москва: Правда, 1989, c. 160.

Словарь изерковно-славянского и русского языка. Т. 2: 3-Н. Санкт-Петербург: Императорская Академия Наук, 1847.

Срезневский, И. И. Материаль для Словаря древне-русского языка по письменным памятникам. T. 2: Л-О. Санкт-Петербург: Типография Императорской Академии Наук, 1902.

Толстой, Н. И. (общ. ред.) Славянские древности: Этнолингвистический словарь: В 5 m. T. 3: К-П. Москва: Международные отношения, 1995.

Ушаков, Д.Н. (ред.) Толковый словарь русского языка. Москва: Государственный институт «Советская энциклопедия», ОГИЗ, Государственное издательство иностранных и национальных словарей, 1935-1940. Режим доступа: http://enc.biblioclub.ru/Termin/1149811_LEBED (2020-03-20).

Филин, Ф. П. (гл. ред.) Словарь русских народных говоров. Вып. 16: КуделяЛесной. Ленинград: Издательство «Наука», 1980. 
Филин, Ф. П. (ред.) Словарь русского языка XI-XVII вв. Вып. 8: Крада-Лящина. Москва: Наука, 1981.

Шанский, Н. М., Боброва, Т. А. Школьный этимологический словарь русского языка: Происхождение слов. Москва: Дрофа, 2004.

Шведова, Н. Ю. (общ. ред.) Русский семантический словарь. Толковылй словарь, систематизированный по классам слов и значений. Москва: РАН, Институт русского языка, 2002.

(c) $\$($ The article is accessible in open access mode under licence CC BY-NC-ND 